\title{
Salt stress and exogenous silicon influence physiological and anatomical features of in vitro-grown cape gooseberry
}

\section{Renata Alves Lara Silva Rezende ${ }^{*}$ Filipe Almendagna Rodrigues ${ }^{1}$ Joyce Dória Rodrigues Soares ${ }^{1}$ Helbert Rezende de Oliveira Silveira ${ }^{2}$ Moacir Pasqual ${ }^{1}$ Gabrielen de Maria Gomes Dias ${ }^{3}$}

\footnotetext{
${ }^{1}$ Universidade Federal de Lavras (UFLA), 37200-000, Lavras, MG, Brasil. E-mail: renata_vga@yahoo.com.br. "Corresponding author. ${ }^{2}$ Centro Universitário Presidente Tancredo de Almeida Neves (UNIPTAN), São João del-Reiei, MG, Brasil.

${ }^{3}$ Universidade da Integração Internacional da Lusofonia Afro-Brasileira (UNILAB), Redenção, CE, Brasil.
}

ABSTRACT: Salt stress is one of several major abiotic stresses that affect plant growth and development, and there are many evidences that silicon can ameliorate the injuries caused by high salinity. This study presents the results of an assay concerning: (1) the effect of in vitro NaClinduced salt stress in cape gooseberry plants and (2) the possible mitigating effect of silicon in saline conditions. For that, nodal segments were inoculated in Murashige and Skoog (MS) medium under salinity (0.5 and $1.0 \% \mathrm{NaCl})$ with different silicic acid concentrations (0, 0.5 and $1.0 \mathrm{~g} \mathrm{L^{-1 }}$. Phytotechnical characteristics, photosynthetic pigments content, and leaf anatomy were evaluated after 30 days. Shoot length, root length, number of leaves and buds, fresh and dry weight, pigment content, stomatal density and leaf blade thickness were drastically reduced by increased salt level. The supply of silicon $\left(1.0 \mathrm{~g} \mathrm{~L} \mathrm{~L}^{-1}\right)$ has successfully mitigated the effect of salinity at $0.5 \% \mathrm{NaCl}$ for chlorophyll, carotenoids, stomatal density and leaf blade thickness. When salt stress was about 1.0\%, Si was not effective anymore. In conclusion, we affirmed that, in in vitro conditions, salt stress is harmful for cape gooseberry plants and the addition of silicon showed effective in mitigating the saline effects of some features.

Key words: Physalis peruviana L., abiotic stress, salinity, pigments, anatomy.

Estresse salino e silício exógeno influenciam características fisiológicas e anatômicas de fisális cultivada in vitro

RESUMO: $O$ estresse salino é um dos tipos de estresses abióticos mais severos que afetam o crescimento e desenvolvimento vegetal e existem muitas evidências de que o silício possa amenizar os danos causados pela elevada salinidade. Este estudo apresenta os resultados de uma pesquisa que investigou: (1) o efeito do estresse salino in vitro induzido por NaCl em plantas de fisális e (2) o possível efeito mitigador do silício nas condições salinas. Para isso, segmentos nodais foram inoculados em meio de cultura Murashige e Skoog com dois niveis de salinidade (0,5 e 1,0\% de $\mathrm{NaCl}$ ) adicionado de ácido silícico $\left(0 ; 0,5\right.$ e 1,0g $\left.\mathrm{L}^{-1}\right)$. Características fitotécnicas, conteúdo de pigmentos fotossintéticos e anatomia foliar foram avaliados aos 30 dias. O comprimento da parte aérea e da raiz, número de folhas e gemas, massa fresca e seca, conteúdo de pigmentos, densidade estomática e espessura do limbo foliar diminuíram drasticamente devido ao aumento do nível de salinidade. A aplicação de 1,0 $\mathrm{g} \mathrm{L}^{-1}$ silício atenuou com sucesso os efeitos salinos para as variáveis conteúdo de pigmentos e anatomia foliar quando a salinidade era de $0,5 \% \mathrm{NaCl}$. Já quando o nível de $\mathrm{NaCl}$ dobrou, o silício não se mostrou efetivo. Concluindo, pode-se afirmar que, em condições in vitro, o estresse salino é prejudicial à fisális e a adição de silicio mostra-se efetiva na mitigação dos efeitos salinos em determinadas características. Palavras-chave: Physalis peruviana L., estresse abiótico, salinidade, pigmentos, anatomia.

\section{INTRODUCTION}

Salt stress is considered one of the major abiotic stresses that can limit the plant growth (ZHU \& GONG, 2014). The impacts of high salinity involves decline in crop yields, reduced water use efficiency, land disuse, contamination of environment and less food supply (FAO, 2015). A biological knowledge of the effects of salt stress is necessary to understand the plant responses and find ways for mitigating the damage (CARILLO et al., 2011).
In this context, salt stress studies using in vitro setups have been proposed to carry out, since they are considered a viable alternative to represent the external environment with its adverse conditions (CLAYES et al., 2014). Furthermore, this type of experiment offers full control of stress level and onset, and low variability (LAWLOR, 2013). Moreover, in vitro approaches also offer better prospects during the selection stage in a breeding program since some environmental limitations can be solved using this system (KHALID \& AFTAB, 2016). 
An alternative recently studied that aimed to reduce the saline effects on plants is to use the silicon fertilization (SAHEBI et al., 2016). Silicon ( $\mathrm{Si}$ ) is found in greater quantities on Earth's crust, and its essentiality for plants has not been proven yet. However, $\mathrm{Si}$ is considered a beneficial element due to favourable effects that can provide, especially in monocots (PILON-SMITS et al., 2009). Many studies reported that $\mathrm{Si}$ presents mitigating effects of abiotic stresses such as salinity and drought (ZHU \& GONG, 2014). Moreover, in vitro culture is a useful system for studying physiological functions of $\mathrm{Si}$ in plants (SIVANESAN \& PARK, 2014).

Cape gooseberry (Physalis peruviana L. Solanaceae) is an herbaceous plant that produces small and sweet globe fruits. In Brazil, is popular in the Northern and Northeastern regions while in Southern and Southeastern it has a still recent cultivation (RODRIGUES et al. 2009), which is expanding, particularly in the Rio Grande do Sul State where the plant can be exploited by small-scale producers (MUNIZ et al., 2014). The world's largest production of cape gooseberry occurs in Colombia, a country that suffers with salinity problems in about 600,000ha of its agricultural area (MIRANDA et al., 2014). In view of all this information, $P$. peruviana was chosen to compose this study due to its increasing importance as an economic alternative for small producers in several Brazilian regions and for its appeal as a plant of medicinal interest for industry. Its cultivation in vitro revealed that cape gooseberry is a non-tolerant plant to salt stress (REZENDE et al., 2017). Thus, it is necessary to increase the knowledge concerning the physiological and anatomical changes to better understand the plant responses and to propose alternatives that mitigates damages, such as the use of Si.

On these grounds, the current research aimed to (1) evaluate the effect of in vitro $\mathrm{NaCl}$ induced salt stress and (2) identify a possible mitigating effect of silicon under high salinity conditions on the physiological and anatomical characteristics of cape gooseberry.

\section{MATERIALS AND METHODS}

\section{Plant material, experimental conditions and treatments}

Seeds of $P$. peruviana (harvested in 2015 in Lavras-MG, Brazil) were immersed briefly in $70 \%$ ethyl alcohol for $1 \mathrm{~min}$, transferred to $30 \%$ aqueous sodium hypochlorite for $30 \mathrm{~min}$, and then washed in sterile distilled water. After the sterilization procedure, the seeds were inoculated individually in $25 \times 150 \mathrm{~mm}$ test tubes containing $15 \mathrm{~mL}$ of culture medium with the salts and vitamins of MS medium (MURASHIGE \& SKOOG, 1962) supplemented with $30 \mathrm{~g} \mathrm{~L}^{-1}$ sucrose and solidified with $1.8 \mathrm{~g} \mathrm{~L}^{-1}$ phytagel. The $\mathrm{pH}$ of the medium was adjusted to 5.8.Plants were sub cultivated twice, at $30 \mathrm{~d}$ intervals, to obtain a satisfactory amount of plants for conducting the experiment.

Equally sized nodal segments $(1.0 \mathrm{~cm}$ long) containing a single axillary bud were used as explants. The segments were inoculated individually in test tubes containing $15 \mathrm{~mL}$ of MS medium added of $30 \mathrm{~g} \mathrm{~L}^{-1}$ sucrose and solidified with $1.8 \mathrm{~g} \mathrm{~L}^{-1}$ phytagel. Culture medium was added of different concentrations of $\mathrm{NaCl}(0.5 \%$ and $1.0 \%)$ and silicic acid $-\mathrm{SiO}_{2} \cdot \mathrm{xH}_{2} 0\left(0,0.5\right.$ and $\left.1.0 \mathrm{~g} \mathrm{~L}^{-1}\right)$. The $\mathrm{pH}$ of the media was adjusted to 5.8. After application of treatments, the explants were maintained in growth room under a 16-hour photoperiod and a fluorescent light intensity of $35 \mu \mathrm{mol} \mathrm{m} \mathrm{m}^{-2} \mathrm{~s}^{-1}$ at $25^{\circ} \mathrm{C} \pm 2^{\circ} \mathrm{C}$.

The experimental design was completely randomized in a factorial scheme $2 \times 3$ (two concentrations of $\mathrm{NaCl}$ and three silicic acid concentrations) + an additional treatment represented by control (without $\mathrm{NaCl}$ and $\mathrm{Si}$ ). Each treatment consisted of 40 test tubes with one plant each. After 30 days, the evaluations were performed.

\section{Phytotechnical analysis}

Number of buds, number of leaves, shoot length $(\mathrm{cm})$, root length $(\mathrm{cm})$, fresh weight of shoot and root $(\mathrm{g})$ and dry weight of shoot and root $(\mathrm{g})$ were evaluated.

\section{Pigments content}

To estimate the pigments content, $10 \mathrm{mg}$ of fresh leaves were soaked in $80 \%$ acetone and the formed extract was filtered using filter paper. The absorbance of the solution were recorded at 663, 645 and 470nm for chlorophyll a, chlorophyll $\mathrm{b}$ and carotenoids, respectively, and the content was calculated according to the methodology of LICHTENTHALER (1987).

\section{Leaf anatomy}

Five leaves were collected from the middle third of plants of each treatment, fixed in $\mathrm{FAA}_{70 \%}$ and stored in $70 \%$ ethanol. Paradermal sections of the abaxial face were performed by hand using stainless steel blades, while the cross-sections were performed on a microtome table. All sections were whitened in $1 \%$ sodium hypochlorite and washed in distilled water; paradermal sections were stained with $1.0 \%$ safranin, and cross-sections were stained 
with safrablau solution $(1.0 \%$ safranin and $0.1 \%$ of astra blue at a 7:3 ratio) and then mounted on semipermanent slides with glycerol 50\% (JOHANSEN, 1940). Samples were viewed on an microscope Olympus CX41 coupled to a digital camera Belcam DIV-3000 and photographed. Measurements were performed using ImageTool 3.0 software. Stomatal density and leaf blade (measured in the fourth vascular bundle region) were assessed.

\section{Statistical analysis}

Statistical analysis was performed with $\mathrm{R}$ software (R Development Core Team, 2008). Data were subjected to analysis of variance and, in case of significant differences of factors or interaction between them, the means were compared by Tukey's test $(P \leq 0.05)$.Comparisons with the additional treatment (control) were analyzed by Dunnett's test $(P \leq 0.05)$.

\section{RESULTS AND DISCUSSION}

\section{Phytotechnical analysis}

There was no significant effect for the interaction $\mathrm{NaCl} \times \mathrm{Si}$, being observed significance for $\mathrm{NaCl}$ only (Figure 1). The increase in salt concentration resulted in a reduction in the shoot length, root length

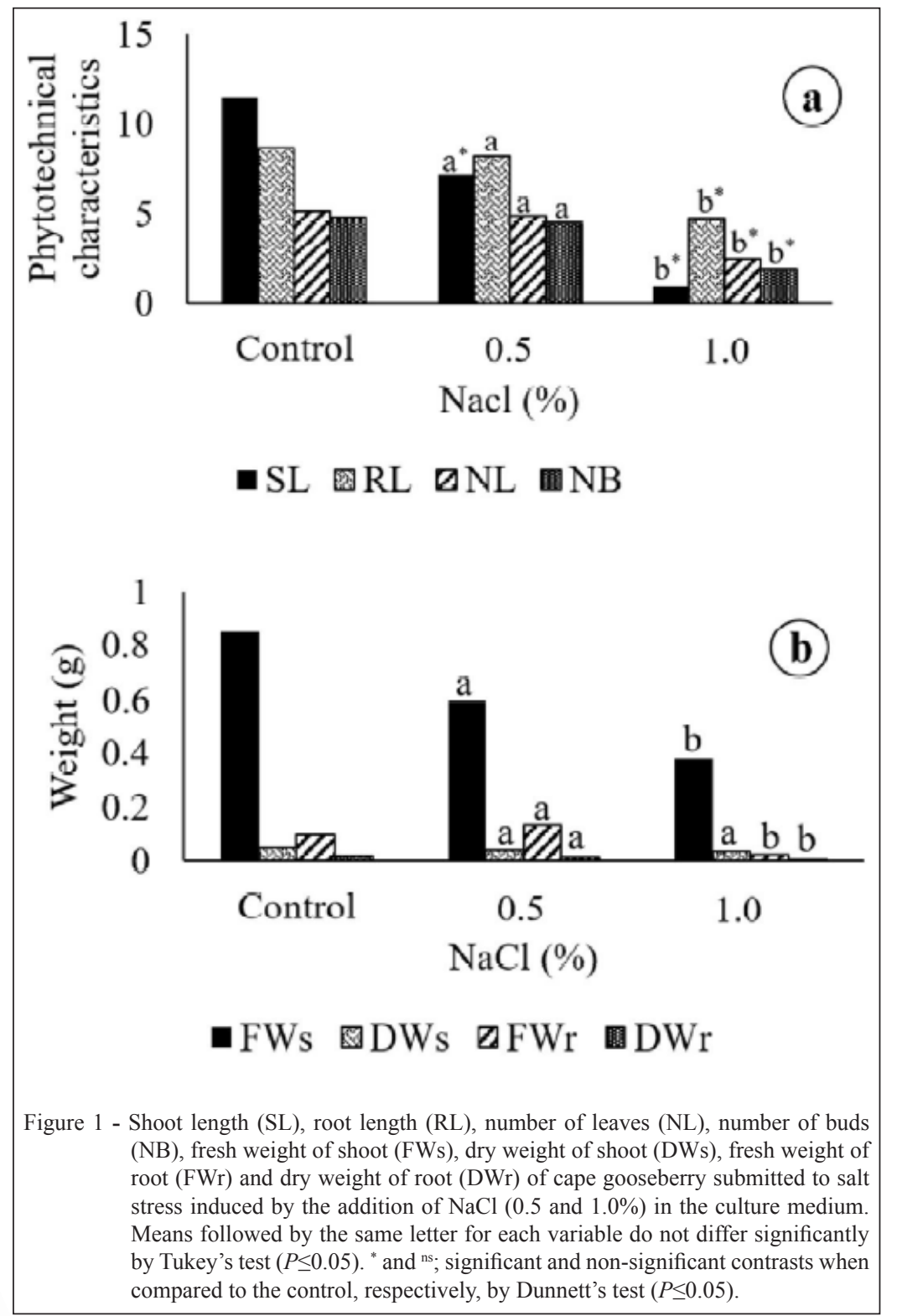

Ciência Rural, v.48, n.1, 2018. 
and number of leaves and buds (Figure 1a). These responses probably occurred due to osmotic effect of the saline solution outside the roots as well as the imbalance of the nutrients uptake and assimilation. High concentrations of salt in the medium disturb the capacity of roots to extract water. Moreover, the high concentrations of salt within the plant can be toxic, resulting in inhibition of many physiological and biochemical process (CARRILLO et al., 2014). One of the early symptoms of exposure to salt stress is the reduction in plant growth, which is due to imbalance of nutrients and to the occurrence of water deficit (YUE et al., 2012). HARTER et al. (2014) and SÁ et al. (2014) also reported a decrease on plant length of gliricidia (Gliricidia sepium) and mogango (Curcubita pepo), respectively, as they increased the $\mathrm{NaCl}$ concentration of culture medium. In this study, the control treatment showed the highest shoot length and the higher concentration of $\mathrm{NaCl}$ was responsible for the lower plant height (Figure 1a).

The root length decreased around 50\% when the salinity was increased from 0.5 to $1 \%$ (Figure 1a). As for the shoot, the reduction of the root system is connected to the lower water absorption caused by the presence of toxic salts that bring on a decline of osmotic potential. It is important to emphasize that the reduction of root length when the salinity was initially imposed ( 0 to $0.5 \%$ ) was less pronounced than the reduction of shoot length. According to CARRILLO et al. (2014), the root growth is less sensitive than the shoot growth to osmotic stress because a reduction in the leaf area, in relation to root growth, decreases the water use by the plant, conserving the medium moisture and preventing the salt concentration in the medium. In this study, the addition of Si did not influence the attenuation of stress in root length.

Number of leaves and buds were reduced by $50 \%$ and $57.5 \%$, respectively, with increasing $\mathrm{NaCl}$ concentration (Figure 1a). The control had the highest values for these variables, and it differed significantly of treatment of $1.0 \% \mathrm{NaCl}$. For fresh weight and dry weight of shoot and root, we did not observe significant interaction, indicating that the $\mathrm{Si}$ was not capable to contribute for attenuation of stress (Figure 1b). In this study, we reported a significant effect for $\mathrm{NaCl}$ isolated, i.e., the increase in its concentration caused a reduction in weight of shoot and root. According to PARIDA \&DAS (2005), the reduction in fresh and dry weight of stems, leaves and roots is one of the symptoms observed in plants grown under salt stress. Over again, these responses are reflections of the water deficit generated by the $\mathrm{NaCl}$ as well as its toxicity, contributing to the reduction of the biomass production by plants. RAHIMI et al. (2012) also verified reduction in fresh and dry weight of fennel plants submitted to salinity.

In general, we observed that the addition of $\mathrm{NaCl}$ to medium was detrimental to cape gooseberry and the supplementation with $\mathrm{Si}$ did not mitigate the deleterious effects of salt. According to BRAGA et al. (2009), the different behaviour observed in species that receive Si can be explained by the fact that the in vitro growth conditions depends on the development of culture media protocols that are optimized for each species and the perfect interaction of components. Most of the studies involving the effect of $\mathrm{Si}$ in the plant was carried out with accumulating species, like the monocots, due to important responses that these plants show in the presence of this element, behaviour that is not often observed for other species, such as those of group of dicots (HODSON et al., 2005). Studies using non-accumulating species of $\mathrm{Si}$ have become more frequent due to the larger quest for understanding the behaviour of these plants in the presence of this element, when compared to the wealth of information that already exists about the $\mathrm{Si}$ accumulation in Poaceae family (ZHU \& GONG, 2014).

\section{Photosynthetic pigments}

The addition of $\mathrm{NaCl}$, regardless of its concentration, reduced pigment content in the leaves of cape gooseberry (Table 1). The total chlorophyll content, for example, decreased by about $40 \%$ as well as carotenoids. The same was observed in cultivars of Stevia rebaudiana regenerated in vitro as well as in rice varieties grown in the presence of $\mathrm{NaCl}$ (JAMIL et al., 2012; RATHORE et al., 2014). The decrease in chlorophyll contents in saltstressed plants can be attributed to the inhibition of nutrients uptake or insufficiency of the essential nutrients (SRINIENG et al., 2015). Moreover, many scientists also suggested that the decrease in chlorophyll levels may possibly be the results of some kind of inhibition of chlorophyll synthesis, together with the increased activity of chlorophyll degrading enzyme chlorophyllase (SANTOS, 2004). Reactive oxygen species (ROS) that form in salinity conditions also cause the chlorophyll degradation and the loss of that pigment is considered one of oxidative damage indicators (YASAR et al., 2008).

When we analyzed the results obtained from the treatments with supplementation with $\mathrm{Si}$, it is possible to note that this element was able to increase the content of chlorophyll a, b and total 
Table 1 - Photosynthetic pigment (chlorophyll a, chlorophyll b, chlorophyll total and carotenoids) content in leaves (in $\mu \mathrm{g} \mathrm{g}^{-1}$ fresh weight), stomatal density (in stomata $\mathrm{mm}^{-2}$ ) on the abaxial face of leaf, and leaf blade thickness (in $\mu \mathrm{m}$ ) of in vitro-grown cape gooseberry plants cultivated under salt stress induced by $\mathrm{NaCl}(0.5$ and $1.0 \%)$ and silicon $(\mathrm{Si})\left(0 ; 0.5\right.$ and $\left.1.0 \mathrm{~g} \mathrm{~L}^{-1}\right)$ as a mitigating element of the stress.

\begin{tabular}{|c|c|c|c|}
\hline \multirow{2}{*}{ Treatments } & \multicolumn{3}{|c|}{ 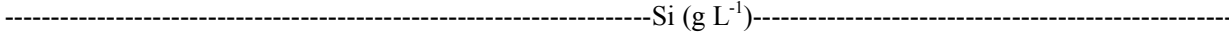 } \\
\hline & 0 & 0.5 & 1.0 \\
\hline \multicolumn{4}{|c|}{-Chlorophyll a-- } \\
\hline \multicolumn{4}{|l|}{ Control } \\
\hline 0.5 & $1.60 \mathrm{aC}^{*}$ & $4.26 \mathrm{aB}^{*}$ & $5.31 \mathrm{aA}^{*}$ \\
\hline \multirow[t]{2}{*}{1.0} & $1.77 \mathrm{aA}^{\mathrm{ns}}$ & $1.89 \mathrm{bA}^{\mathrm{ns}}$ & $1.41 \mathrm{bA}^{*}$ \\
\hline & (2) & Chlorophyll & -----------. \\
\hline Control & & 1.22 & \\
\hline 0.5 & $0.72 b^{*}$ & $1.68 \mathrm{aB}^{*}$ & $2.15 \mathrm{aA}^{*}$ \\
\hline \multirow[t]{2}{*}{1.0} & $1.15 \mathrm{aA}^{\mathrm{ns}}$ & $1.04 \mathrm{bA}^{\mathrm{ns}}$ & $1.14 \mathrm{bA}^{\mathrm{ns}}$ \\
\hline & 西- & tal chloroph & 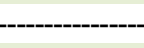 \\
\hline Control & & 4.19 & \\
\hline 0.5 & $2.32 \mathrm{aC}^{*}$ & $5.94 \mathrm{~B} \mathrm{a}^{*}$ & $7.46 \mathrm{aA}^{*}$ \\
\hline \multirow[t]{2}{*}{1.0} & $2.92 \mathrm{Aa}^{\mathrm{ns}}$ & $2.94 \mathrm{bA}^{\mathrm{ns}}$ & $2.55 \mathrm{bA}^{*}$ \\
\hline & 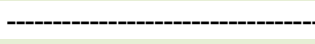 & -Carotenoid & -------------- \\
\hline Control & & 1.38 & \\
\hline 0.5 & $0.82 \mathrm{aC}^{*}$ & $2.02 \mathrm{aB}^{*}$ & $2.55 \mathrm{aA}^{*}$ \\
\hline \multirow[t]{2}{*}{1.0} & $0.89 \mathrm{aA}^{\mathrm{ns}}$ & $0.98 \mathrm{bA}^{\mathrm{ns}}$ & $0.76 \mathrm{bA}^{*}$ \\
\hline & ---- & tomatal den & -------------. \\
\hline Control & & 45 & \\
\hline 0.5 & $32 \mathrm{aC}^{*}$ & $47 \mathrm{aA}^{\mathrm{ns}}$ & $41 \mathrm{aB}^{\mathrm{ns}}$ \\
\hline \multirow[t]{2}{*}{1.0} & $24 \mathrm{bA}^{*}$ & $27 \mathrm{bA}^{*}$ & $25 \mathrm{bA}^{*}$ \\
\hline & 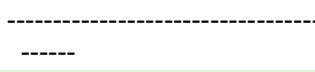 & Leaf blade & ----------------- \\
\hline Control & & 186.75 & \\
\hline 0.5 & $178.61 \mathrm{aB}^{\mathrm{ns}}$ & $340.62 \mathrm{aA}^{*}$ & $219.70 \mathrm{aB}^{\mathrm{ns}}$ \\
\hline 1.0 & $344.14 \mathrm{bB}^{*}$ & $360.71 \mathrm{aB}^{*}$ & $441.83 \mathrm{bA}^{*}$ \\
\hline
\end{tabular}

Means followed by the same lower-case letter in the column and upper-case letter in the row for each variable are not significantly different at $P \leq 0.05$ using Tukey's test. ${ }^{*}$ and ${ }^{\text {ns }}$; significant and non-significant contrasts when compared to the control, respectively, by Dunnett's test $(P \leq 0.05)$.

as well as carotenoids when we used the lowest $\mathrm{NaCl}$ concentration $(0.5 \%)$ (Table 1$)$. Probably this improvement is related to the occurrence of possible anatomic changes, as was reported by ASMAR et al. (2011). Such modifications may be related to the greater thickness of some tissues, which have pigments. However, when we observed the pigment content at $1 \% \mathrm{NaCl}$, we noted that even using $1.0 \mathrm{~g} \mathrm{~L}^{-1}$ of $\mathrm{Si}$, it is not possible to increase the pigment content, indicating that the stress imposed to the plants was sufficient high enough to cause severe damage. These results corroborated the SOUNDARARAJAN et al. (2013) ones who observed an increase in the contents of chlorophyll a, b and total in sage leaves under lower concentration of $\mathrm{NaCl}$ and the presence of $\mathrm{Si}$. In higher concentrations of salt, the pigments content were not increased, even when used high doses of
Si. This behaviour was not observed in fennel plant (Foeniculum vulgaris) subjected to salt stress, which did not present their chlorophyll content increased with addition of Si (RAHIMI et al., 2012).

The higher $\mathrm{NaCl}$ concentrations led to the occurrence of lower values for carotenoids (Table 1). However, at a concentration of $0.5 \%$ $\mathrm{NaCl}$ plus supplementation with $\mathrm{Si}$, there was an increase in carotenoid content, which is linked to the presence of $\mathrm{Si}$ in the culture medium. Although there are no studies with application of $\mathrm{Si}$ on $P$. peruviana, it is expected that this species, as well as tomato, behave as a non-accumulating plant, because they belong to the same family. However, according to CURRIE \&PERRY (2007), even the plant not being able to accumulate Sidue to some kind of mechanism that hinders the absorption of 


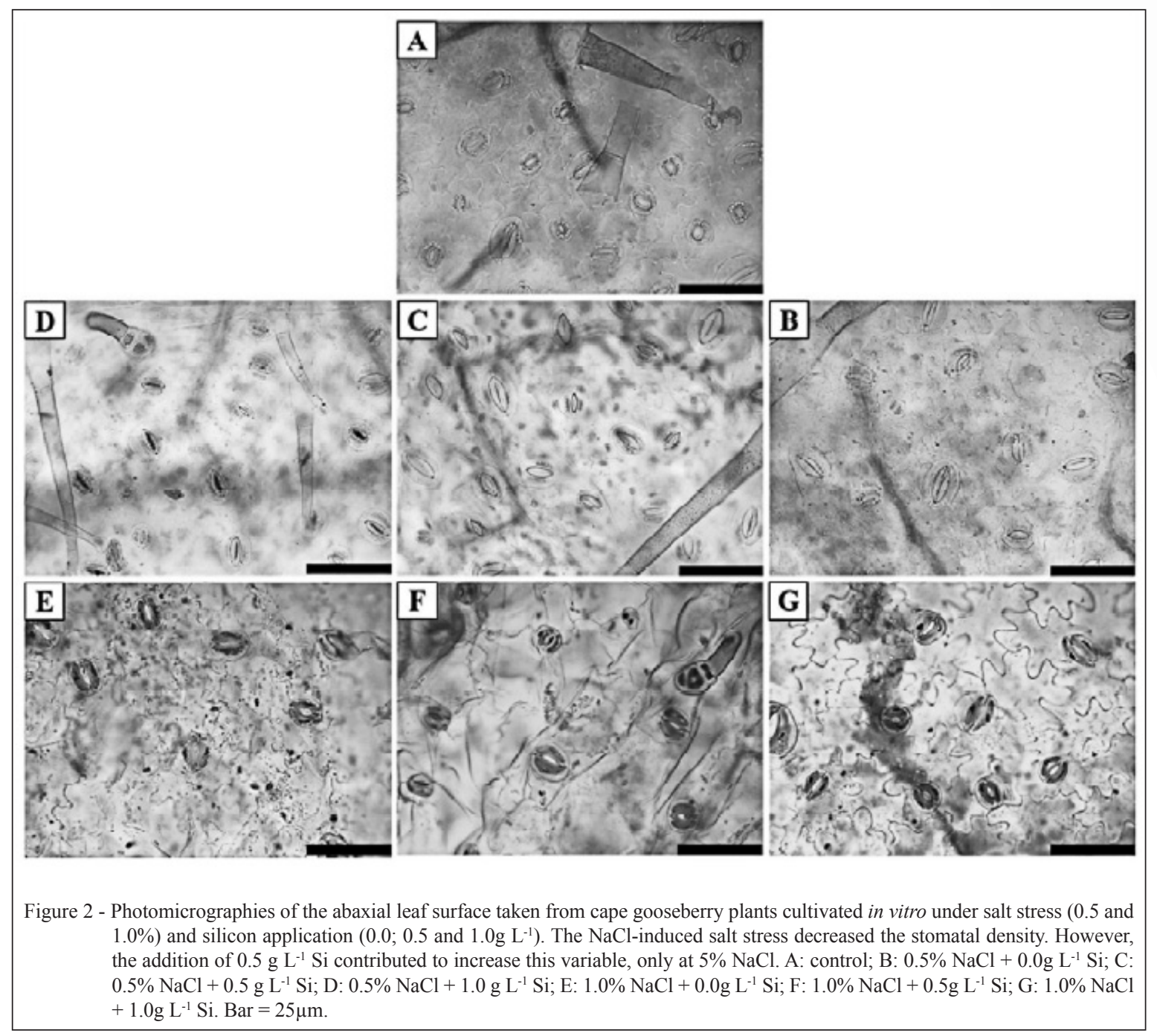

this element, the absorption of Si can be triggered by stimulation of protection against diseases, pests and other stress conditions.

\section{Leaf anatomy}

The leaf anatomy has also been modified by the action of $\mathrm{NaCl}$ and $\mathrm{Si}$ (Table 1). Stomatal density (number of stomata $\mathrm{mm}^{-2}$ ) was reduced when the salinity increased. Some researchers have shown that salt stress causes a reduction in the number of stomata, such as the studies performed by ROMEROARANDA et al.(2001) and PARIDA et al. (2004) showing the reduction in stomatal density of tomato cultivars and Bruguiera parviflora leaves under salt stress. However, it remains unknown the mechanisms by which salinity regulates this feature. In quinoa (Chenopodium quinoa), SHABALA et al. (2012) reported an association between increased salinity and consequent decrease in stomatal density. The authors related this reduction to the increase in leaf succulence, which is the thickening of the leaf tissue with resulting increase of sap volume. The increased leaf succulence is an adaptive response of glycophyte plants and occurs by increasing the mesophyll cells and the vacuoles and it is proposed that it be a direct response to the effect of salinity in order to increase the storage area of $\mathrm{Na}^{+}$and $\mathrm{Cl}^{-}$(SHABALA \& MAKAY, 2011).

In this study, the stomatal density was reduced by about 40 and $87.5 \%$ when $\mathrm{NaCl}$ was added at concentrations of 0.5 and $1.0 \%$, respectively (Table 1). However, we observed that at $0.5 \% \mathrm{NaCl}$, the addition of $\mathrm{Si}$ was effective for increase the stomatal density. When all treatments are compared to the control, it is possible verify that in treatments where there was addition of $0.5 \mathrm{~g} \mathrm{~L}^{-1} \mathrm{Si}$ the number of stomata $\mathrm{mm}^{-2}$ did not differ from control, thus 
indicating the performance of $\mathrm{Si}$ in mitigating the harmful effect of the salt, which had reduced density (Table 1). Figure 2 clearly illustrates this behaviour showing that the addition of $\mathrm{NaCl}$ reduced the stomatal density compared to the control. However, at $5 \% \mathrm{NaCl}$, the addition of $0.5 \mathrm{~g} \mathrm{~L}^{-1}$ of Si promoted the increase of this variable indicating the contribution of this element to the reestablishment of a number of stomata close to the control.

Si can act in increasing the density in order to increase the $\mathrm{CO}_{2}$ capture and keep the photosynthetic rate. The increase in stomatal density in plants grown in vitro with the addition of Si has been reported in the literature (ASMAR et al., 2011; DIAS et al., 2014.).

Increased salinity caused a significant increase in leaf blade thickness. In the media with $0.5 \% \mathrm{NaCl}$, the addition of $0.5 \mathrm{~g} \mathrm{~L}^{-1} \mathrm{Si}$ favoured increased thickness, while in the medium with high salt plus $1.0 \mathrm{~g} \mathrm{~L}^{-1} \mathrm{Si}$ resulted in a greater thickening of the leaf blade. Interestingly, in short, the increase in salt stress levels provided an increase in leaf blade thickness. This result is in line with those obtained for the stomatal density when taking into account the leaf succulence. It has been remarked that an increase in tissue thickness, i.e., increased succulence leaf is a response to exposure of the plants to salinity. For the storage of $\mathrm{Na}^{+}$and $\mathrm{Cl}$-ions and water turns more effective, the plant tends to increase the blade thickness in order to increase the storage area. It is noteworthy that the increase in this area also helps to maintain levels of pigments such as chlorophyll, since that for area increase is necessary that the mesophyll tissues, including those with pigments, becomes thicker. In this study, this behaviour could be clearly seen.

\section{CONCLUSION}

In in vitro conditions, salinity is harmful to cape gooseberry plants. The lowest concentration used is enough to cause injuries in tissues of plants and consequently in their physiology. The use of an exogenous silicon source is an alternative to ameliorate the stress generated, and in the case of this study, the silicon is effective to mitigate the damage to the photosynthetic pigments, number of stomata, and leaf blade thickness.

\section{ACKNOWLEDGEMENTS}

To the Conselho Nacional de Desenvolvimento Científico e Tecnológico (CNPq), Fundação de Amparo à Pesquisa do Estado de
Minas Gerais (FAPEMIG) and Coordenação de Aperfeiçoamento de Pessoal de Nível Superior (CAPES) for financial support.

\section{REFERENCES}

ASMAR, S.A. et al. Sources of silicon in the development of micropropagated seedlings of banana 'Maçã'. Ciência Rural, v.41, n.7, p.1127-1131, 2011. Available from: $<$ http://www.scielo.br/scielo.php?script $=$ sci arttext\&pid $=$ S0103-84782011000700003 $>$. Accessed: Feb. 13, 2017. doi: $10.1590 / \mathrm{S} 0103-84782011005000086$

BRAGA, F.T. et al. Anatomical characteristics of strawberry seedlings micropropagated using different sources of silicon. Pesquisa Agropecuária Brasileira, v.44, n.2, p.128-132, 2009. Available from: <http://www.scielo.br/scielo.php?pid=S0100204X2009000200003\&script $=$ sci arttext\&tlng=en $>$. Accessed: Feb. 15, 2017. doi: 10.1590/S0100-204X2009000200003.

CARILlO, P. et al. Salinity stress and salt tolerance. In: SHANKER, A.; VENKATESWARLU, B. Abiotic stress in plants - Mechanisms and adaptations. Rijeka: InTech, 2011. Cap.2, p.21-38. doi: 10.5772/22331.

CLAYES, H. et al. What is stress?: dose-response effects in commonly used in vitro stress assays. Plant Physiology, v.165, n.1, p.519-517, 2014. Available from: <https://www.ncbi.nlm.nih. gov/pubmed/24710067>. Accessed: Jan. 31, 2017. doi: 10.1104/ pp.113.234641.

CURRIE, H.A.; PERRY, C.C. Silica in plants: biological, biochemical and chemical studies. Annals of Botany, v.100, n.7, p.1383-1389, 2007. Available from: <https://www.ncbi.nlm.nih. gov/pmc/articles/PMC2759229/>. Accessed: Mar. 01, 2017. doi: $10.1093 / \mathrm{aob} / \mathrm{mcm} 247$.

DIAS, G.M.G. et al. Photosynthesis and leaf anatomy of Anthurium cv. 'Rubi' plantlets cultured in vitro under different silicon (Si) concentrations. Australian Journal of Crop Science, v.8, n.8, p.1160-1167, 2014. Available from: <http://www.cropj.com/ dias_8_8_2014_1160_1167.pdf >.Accessed: Oct. 7, 2017.

FAO. Impacts of salinization, sodication and waterlogging FAO Soils Portal. Online. Available from: <http://www.fao.org/ soils-portal/soil-management/management-of-some-problemsoils/salt-affected-soils/more-information-on-salt-affected-soils/ en/>. Accessed: Feb. 13, 2017.

HARTER, L.S.H. et al. Effect of salinity on physiological performance of mogango seeds and seedlings. Horticultura Brasileira, v.32, n.1, p.80-85, 2014. Available from: <http://www.scielo.br/scielo. php? script $=$ sci arttext\&pid $=$ S0102-05362014000100080>. Accessed: Oct. 21, 2017. doi: 10.1590/S0102-05362014000100013.

HODSON, M.J. et al. Phylogenetic variation in the silicon composition of plants. Annals of Botany, v.95, n.1, p.10271046, 2005. Available from: <https://academic.oup.com/aob/ article/96/6/1027/216512/Phylogenetic-Variation-in-the-SiliconComposition>. Accessed: Jan. 11, 2017. doi: 10.1093/aob/mci255.

JAMIL, M. et al. Effect of salinity on physiological and biochemical characteristics of different varieties of rice. Pakistan Journal of Botany, v.44, n.2, p.7-13, 2012. Available from: $<$ http://citeseerx. ist.psu.edu/viewdoc/download?doi=10.1.1.658.6914\&rep=rep1\&t ype=pdf $>$. Accessed: Jan. 15, 2017. 
JOHANSEN, D.A. Plant microtechnique. New York: McGrawHill, 1940. 523p.

KHALID, A.; AFTAB, F. Effect of exogenous application of 24-epibrassinolide on growth, protein contents, and antioxidant enzyme activities of in vitro-grown Solanum tuberosum L. under salt stress. In Vitro Cellular \& Developmental Biology-Plant, v.52, n.1, p.81-91, 2016. Available from: <https://link.springer. com/article/10.1007/s11627-015-9745-2>. Accessed: Dec. 14, 2017. doi: 10.1007/s11627-015-9745-2.

LAWLOR, D.W. Genetic engineering to improve plant performance under drought: physiological evaluation of achievements, limitations, and possibilities. Journal of Experimental Botany, v.64, n.1, p.83-108, 2013. Available from: <https://www. researchgate.net/publication/233539301_Genetic_engineering to improve plant performance under drought Physiological evaluation_of achievements limitations and possibilities $>$. Accessed: Mar. 13, 2017. doi: $10.1093 /$ jxb/ers326.

LICHTENTHALER, H.K. Chlorophylls and carotenoids: pigment photosynthetic biomembranes. Methods in Enzymology, v.148, n.1, p.362-385, 1987.

MIRANDA, D. et al. Salinity effects on proline accumulation and total antioxidant activity in leaves of the cape gooseberry (Physalis peruviana L.). Journal of Applied Botany and Food Quality, v.87, n.1, p.67-73, 2014. Available from: <https://ojs.openagrar de/index.php/JABFQ/article/view/2303/3187>. Accessed: Jan. 22, 2017. doi: 10.5073/JABFQ.2014.087.010.

MUNIZ, J. et al. General aspects of physalis cultivation. Ciência Rural, v.44, n.6, p.964-970, 2014. Available from: $<$ http://www.scielo.br/scielo.php?script=sci_arttext\&pid $=$ S0103-84782014000600002 $>$. Accessed: Jan. 06, 2017. doi: $10.1590 / \mathrm{S} 0103-84782014005000006$.

MURASHIGE, T.; SKOOG, F. A revised medium for rapid growth and bioassays with tobacco tissue cultures. Physiologia Plantarum, v.15, n.1, p.473-497, 1962. Available from: <http:// onlinelibrary.wiley.com/doi/10.1111/j.1399-3054.1962.tb08052.x/ abstract>. Accessed: Dec. 15, 2016. doi: 10.1111/j.13993054.1962.tb08052.x

PARIDA, A.K.; DAS, A.B. Salt tolerance and salinity effects on plants: a review. Ecotoxicology and Environmental Safety, v.60, n.3, p.324-349, 2005. Available from: <http:/www.sciencedirect. com/science/article/pii/S0147651304000922>. Accessed: Jan. 15, 2017. doi: 10.1016/j.ecoenv.2004.06.010.

PARIDA, A.K. et al. Effects of salt on growth, ion accumulation, photosynthesis and leaf anatomy of the mangrove, Bruguiera parviflora. Trees, v.18, n.2, p.167-174, 2004. Available from: $<$ https://link.springer.com/article/10.1007/s00468-003-0293-8 > Accessed: Oct. 12, 2016.

PILON-SMITS, E.A. et al. Physiological functions of beneficial elements. Current Opinion in Plant Biology, v.12, n.3, p.267274, 2009. Available from: <http://www.sciencedirect.com science/article/pii/S1369526609000326>. Accessed: Feb. 18, 2017. doi: 10.1016/j.pbi.2009.04.009.

R DEVELOPMENT CORE TEAM. R: a language and environment for statistical computing. Vienna: R Foundation for Statistical Computing. 2008. Available from: <http://www.R-project.org $>$. Accessed: Sept. 15, 2016
RAHIMI, R. et al. Effects of salt stress and silicon nutrition on chlorophyll content, yield and yield components in fennel (Foeniculum vulgar Mill.). International Journal of Agriculture and Crop Science, v.4, n.21, p.1591-1595, 2012. Available from: $<$ http://pakacademicsearch.com/pdf-files/agr/70/1591-1595.pdf $>$. Accesssed: Oct. 12, 2016.

RATHORE, S. et al. Influence of $\mathrm{NaCl}$ on biochemical parameters of two cultivars of Stevia rebaudiana regenerated in vitro. Journal of Stress Physiology and Biochemistry, v.10, n.2, p.287-296, 2014. Available from: <http://agris.fao.org/agris-search/search. do?recordID=RU2015103062>. Accessed: Dec. 13, 2016.

REZENDE, R.A.L.S. et al. Effects of silicon on antioxidant enzymes, $\mathrm{CO}_{2}$, proline and biological activity of in vitro-grown cape gooseberry under salinity stress. Australian Journal of Crop Science, v.11, n.4, p.438-446, 2017. Available from: <http://www. cropj.com/rezende_11_4_2017_438_446.pdf >. Accessed: Sept. 11, 2016. doi: $10.2 \overline{1} 47 \overline{75} / \overline{a j}$ cs. $1 \overline{7} \cdot 11.04 .335$.

RODRIGUES, E. et al. Minerals and essential fatty acids of the exotic fruit Physalis peruviana L. Ciência e Tecnologia de Alimentos, v.29, n.3, p.642-645, 2009. Available from: <http://www.scielo.br/ scielo.php?script=sci arttext\&pid=S0101-20612009000300029>. Accessed:Oct. 14, 2017. doi: 10.1590/S0101-20612009000300029.

ROMERO-ARANDA, M.R. et al. Tomato plant: water uptake and plant-water relationships under saline growth conditions. Plant Science, v.160, n.2, p.265-272, 2001. Available from: <http:// www.sciencedirect.com/science/article/pii/S0168945200003885>. Accessed: Oct. 21, 2017. doi: 10.1016/S0168-9452(00)00388-5.

SÁ, F.P. et al. Initial development in vitro of gliricidia in different levels of salinity. Scientia Plena, v.10, n.4, p.1-7, 2014. Available from: <https://www.scientiaplena.org.br/sp/article/ view/1596/982>. Accessed: Nov. 13, 2017.

SAHEBI, M. et al. Application of silicon in plant tissue culture. In Vitro Cellular and Developmental Biology-Plant, v.52, n.3, p.226-232, 2016. Available from: <https://ink.springer.com/ content/pdf/10.1007\%2Fs11627-016-9757-6.pdf>. Accessed: Dec. 18, 2016. doi: 10.1007/s11627-016-9757-6.

SANTOS, C.V. Regulation of chlorophyll biosynthesis and degradation by salt stress in sunflower leaves. Scientia Horticulturae, v.103, n.1, p.93-99, 2004. Available from: $<$ http:// www.sciencedirect.com/science/article/pii/S0304423804000913>. Accessed: Nov. 18, 2016. doi: 10.1016/j.scienta.2004.04.009.

SHABALA, L. et al. Oxidative stress protection and stomatal patterning as components of salinity tolerance mechanism in quinoa (Chenopodium quinoa). Physiologia Plantarum, v.146, n.1, p.26-38, 2012. Available from: <https://www.ncbi. nlm.nih.gov/pubmed/22324972>. Accessed: Jan. 26, 2017. doi: 10.1111/j.1399-3054.2012.01599.x.

SHABALA, S.; MACKAY, A. Ion transport in halophytes. Advances in Botanical Research, v.57, n.1,p.151-187, 2011. Available from: <http://www.sciencedirect.com/science/article/ pii/B9780123876928000059?via\%3Dihub>. Accessed: Nov. 25, 2017. doi: 10.1016/B978-0-12-387692-8.00005-9.

SIVANESAN, I.; PARK, S.W. The role of silicon in plant tissue culture. Frontiers in Plant Science, v.5, n.571, p.1-4, 2014. Available from: < https://www.ncbi.nlm.nih.gov/pmc/articles/PMC4204432/>. Accessed: Dec. 05, 2017. doi: 10.3389/fpls.2014.00571. 
SOUNDARARAJAN, P. et al. Silicon promotes shoot proliferation and shoot growth of Salvia splendens under salt stress in vitro. Horticulture, Environment and Biotechnology, v.54, n.4, p.311318, 2013. Available from: <https://link.springer.com/content/ pdf/10.1007\%2Fs13580-013-0118-7.pdf >. Accessed: Nov. 13, 2016. doi: 10.1007/s13580-013-0118-7.

SRINIENG, K. et al. Effect of salinity stress on antioxidative enzyme activities in tomato cultured in vitro. Pakistan Journal of Botany, v.47, n.1, p.1-10, 2015. Available from: <https://www. pakbs.org/pjbot/PDFs/47(1)/01.pdf>. Accessed: Dec. 18, 2016.

YASAR, F. et al. Effect of salt stress on antioxidant defense systems, lipid peroxidation, and chlorophyll content in green bean. Russian Journal of Plant Physiology, v.55, n.6, p.782-
786, 2008. Available from: <https://link.springer.com/content/ pdf/10.1134\%2FS1021443708060071.pdf>. Accessed: Dec. 18, 2016. doi: 10.1134/S1021443708060071.

YUE, Y. et al. SOS1 gene overexpression increased salt tolerance in transgenic tobacco by maintaining a higher $\mathrm{K}^{+} / \mathrm{Na}^{+}$ratio. Journal of Plant Physiology, v.169, n.1, p.255-261, 2012. Available from: $<$ https://www.ncbi.nlm.nih.gov/pubmed/22115741>. Accessed: Dec. 3, 2016. doi: 10.1016/j.jplph.2011.10.007.

ZHU, Y.; GONG, H. Beneficial effects of silicon on salt and drought tolerance in plants. Agronomy for Sustainable Development, v.34, n.2, p.455-472, 2014. Available from: <https://link.springer. com/article/10.1007/s13593-013-0194-1>. Accessed: Oct. 7, 2016. doi: $10.1007 / \mathrm{s} 13593-013-0194-1$. 